DOI: 10.20472/EFC.2018.010.016

\title{
WŁODZIMIERZ KOŁODZIEJCZAK
}

Poznań University of Life Sciences, Faculty of Economics and Social Sciences, Poland

\section{ESTIMATION OF THE EQUILIBRIUM UNEMPLOYMENT LEVEL AS A TOOL FOR ASSESSING THE RURAL POPULATION'S OCCUPATIONAL SITUATION: AN EXAMPLE OF POLAND}

\begin{abstract}
:
The purpose of this paper is to present the possible uses of the method developed by the Centre for Economic Policy Research (Unemployment 1995) for estimating the structural unemployment level in selected population groups based on the analysis of flows to/from employment, unemployment and inactivity. Though the method is quite old and has met criticism, it is still reasonable to use it because it enables the decomposition of unemployment into the structural and cyclical component at various levels, limited only by data availability. Also, it is highly suitable for the analysis of data retrieved from the EU-wide Labour Force Survey (LFS). Calculating the flow rates and equilibrium unemployment levels for particular rural population groups selected by defined characteristics, assessing how they evolve over time, and comparing the results between different population groups (e.g. urban dwellers) can be a basis for drawing conclusions on the determinants of changes in economic activity and on the structural or cyclical nature of unemployment. This information is essential for a proper selection of measures taken to counteract adverse developments in the labour market, and enables a more efficient search for solutions designed to improve the population's occupational and economic status. The possible uses of that method are illustrated by the example of the Polish rural population and by calculations based on 2016 data.
\end{abstract}

\section{Keywords:}

unemployment decomposition, LFS, equilibrium rate of unemployment, unemployment natural rate, rural areas

JEL Classification: J21, J64 


\section{Introduction}

For many years, the research on the population's occupational situation has been focused on analysing the indexes related to their demographic, economic and occupational status, relation to agriculture and other characteristics. Usually, analyses were performed in a context of the general economic and social situation. The research followed a static approach or described the evolution taking place within a defined time horizon. Also used were the descriptive method and descriptive statistics or some more sophisticated statistical methods, including econometric modelling. This approach was enough to deliver much valuable information and enabled the formulation of significant conclusions on the subject matter of research, thus helping to plan and implement the economic policy (especially to the extent of rural areas). However, when conducted in such a manner, the analyses imposed considerable limitations which included in particular the difficulties in identifying the causal links and in drawing conclusions on smaller geographic areas or population groups. An equally important obstacle was the inability to precisely identify the determinants of developments in the labour market, especially as regards classifying them into the group related to the characteristics of the rural population and local labour markets and the one related to the general condition of the market for goods and services. The traditional approach failed to deal with this issue. Therefore, it became imperative to use other research methods and approaches.

This is a methodological paper which discusses the opportunities for extending the conclusions on the population's occupational situation brought by the estimation of the structural unemployment level based on the analysis of flows to/from employment, unemployment and inactivity, as developed by (Unemployment 1995). Though the method is quite old and has met criticism (cf. Tyrowicz 2011), it is still reasonable to use flow-based methods because they enable the decomposition of unemployment into the structural and cyclical component at various levels, limited only by data availability. Also, they are highly suitable for the analysis of data retrieved from the EU-wide Labour Force Survey (LFS). Although the examples presented in this paper relate to the Polish rural population, the methods discussed may be used for each territory and each population group as long as appropriate LFS data is available.

The purpose of this paper is to present the possible uses of the method developed by the Centre for Economic Policy Research (Unemployment 1995) for estimating the structural unemployment level in selected population groups based on the analysis of flows to/from employment, unemployment and inactivity. The possible uses of that method are illustrated by the example of the Polish rural population and by calculations based on 2016 data.

In the Polish realities, the place of registered residence may be used as the criterion for isolating the rural areas to be covered by the study (rural municipalities; unlike in EU-15 where population density is used as the criterion). Note that the rural population, despite 
their unquestionable connection to the local labour market, share the same nationwide market (and often even the international market) with the urban population, and that both populations often compete for jobs. Therefore, the most appropriate solution seems to be to put the research in a broad territorial context, taking into account the situation of the urban population (which is also very heterogeneous in terms of occupational situation).

\section{Decomposition of unemployment}

Real unemployment is determined by two basic groups of factors affecting the relationships between labour supply and demand:

- wage factors, i.e. salaries, bonuses, guaranteed employee benefits, labour taxation and other which affect labour costs and real salaries (primarily including the influence of trade unions and unemployment benefits),

- non-wage factors (mainly including human capital, economic conditions, business cycles affecting different industries and international trade, legal regulations, GDP level and growth rate).

The determinants of unemployment level may also be classified as structural or cyclical factors (Fig. 1). Structural unemployment (in a broader sense) is assimilated to natural (equilibrium) unemployment. It includes frictional unemployment, structural employment in the narrow sense and institutional unemployment caused by labour market rigidities resulting from legal regulations and activity of labour market institutions (Socha and Sztanderska 2002).

In the narrow sense, structural unemployment (Fig. 1) includes the mismatch between labour supply and demand structures in particular micro-markets. This may occur even if an equilibrium exists between aggregate supply of labour and aggregate demand for labour on a market-wide basis (Jackman and Roper 1987, Socha and Sztanderska 2002). The reasons for the mismatch is the technical progress, geographical distribution of labour and vacant jobs, and structural changes in the economy. Usually, these factors have a combined impact and the mismatch persists over a long time. Frictional unemployment results from the natural movement of labour force. It occurs because some time is required (depending on the operational efficiency of the labor market) before the job seeker finds a matching vacancy (Burda and Wyplosz 1995). Institutional unemployment is caused by labour market rigidities resulting from legal regulations and activity of labour market institutions (Socha and Sztanderska 2002). The unemployment level which corresponds to the equilibrium between labour supply and demand, defined as natural (equilibrium) unemployment, is the simplest approximation of the unemployment level which the economy tries to achieve in the long run (Burda and Wyplosz 1995, Socha and Sztanderska 2002). Socha and Sztanderska (2002), quoting Haltiwanger (1991), indicate that equilibrium unemployment means an unemployment 
level which the dynamic system tries to achieve under conditions of general stochastic equilibrium. It takes into account the actual structural characteristics of the markets for labour and goods, including market inefficiencies, costs of job seeking and mobility costs. Broadly speaking, equilibrium unemployment is impacted by the financial mismatch (as the wage level expected by the labour force exceeds that offered by the employers under defined economic conditions) and by the mismatch between vacant jobs and the qualitative characterization of the labour force (age, gender, education, location, skills, motivation, permissions etc.). The second component of real unemployment is cyclical unemployment which emerges when, because of a downturn in the market for goods and services and a decrease in demand, less workers are required. The impact of structural and cyclical factors on the development of real unemployment may vary in strength.

Figure 1. Unemployment types

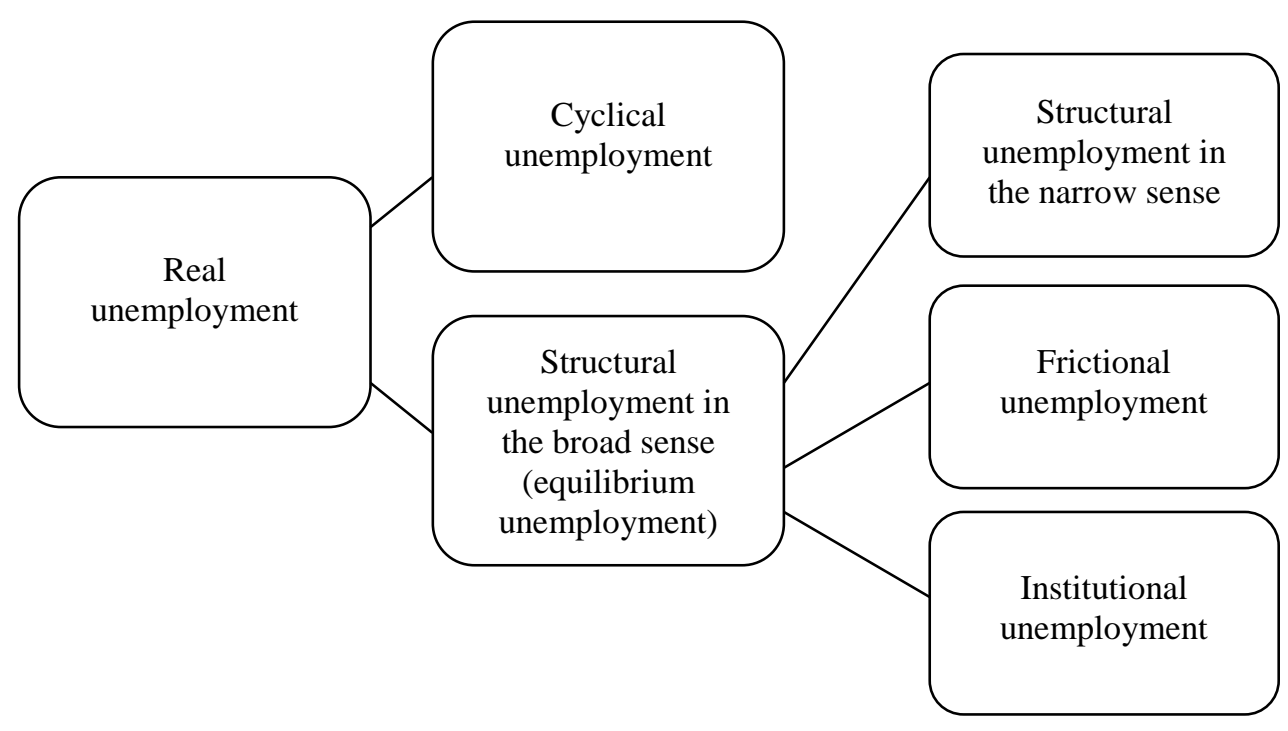

Źródło: Burda i Wyplosz (1995), Socha i Sztanderska (2002), Kwiatkowski (2002b).

Although unemployment consists of structural and cyclical components, and the amount of total demand for labour is primarily determined by the economic growth rate and longterm profitability of increased employment, the opportunities for employment growth are conditioned by the long-term structural unemployment rate (i.e. unemployment at equilibrium point, broadly speaking) (Sztanderska 1999). If the unemployment rate at equilibrium point is known, it allows to estimate how much of the unemployment present in the economy does not depend on short-term fluctuations in the market for goods and services (Socha and Sztanderska 2002), i.e. what is the structural part and cyclical part of unemployment. This information is a basis for determining the type of measures taken to 
increase employment and/or decrease unemployment ${ }^{1}$ : a high share of structural unemployment in real unemployment is a reason to implement programs aimed at improving the balance between supply and demand sides of the labour market and removing non-cyclical barriers (including wage-related barriers) to employment. In turn, a large share of cyclical (Keynesian) unemployment suggests that measures should be undertaken to stimulate economic growth².

\section{Estimating the equilibrium rate of unemployment}

Equilibrium unemployment may be estimated with methods based on the Phillips curve or on the hypothesis of rational expectations and neutrality of money (Socha and Sztanderska 2002), i.e. on NAIRU (Non-Accelerating Inflation Rate of Unemployment) and NAWRU (Non-Accelerating Wage Rate of Unemployment). These methods rely on models which use market variables (including inflation rate, labour productivity and interest rates) (Socha and Wojciechowski 2004). They may provide a correct estimation depending on many factors, including exactness of wage and inflation data, assumptions for employee expectations and behaviour and uncertainty as to the selection of the proper econometric model and inflation equation parameters. The use of these methods is usually restricted to aggregate data because it is difficult to provide a reliable NAIRU or NAWRU estimation for population groups identified based on selected qualitative characteristics. NAIRU may also be estimated based on models underpinned by the assumptions of the Beveridge curve (inverse relation between unemployment and number of vacant jobs). Another approach consists in estimating the NAIRCU (Non Accelerating Inflation Rate of Capacity Utilization) level with the use of the Okun's law. However, this is rarely done because the estimators are difficult to determine (especially the capital utilization rate) (Socha and Sztanderska 2002, Kołodziejczak and Wysocki 2013). The methods discussed above cannot be directly used in a research related to the rural population as the calculations may not be performed for population groups selected by defined characteristics (e.g. place of residence).

Equilibrium unemployment may also be estimated by analysing the volume and structure of flows from/to the populations' economic activity statuses (employment, unemployment and inactivity). Equilibrium unemployment is assumed to exist when inflows to and outflows from other economic activity statuses are equal. According to Socha and Sztanderska (2002), the most important methods based on this assumption include: the method by Darby, Haltiwanger and Plant (1986); the method presented in a report by the

\footnotetext{
1 In the labor market, the labor force flows to and from inactivity. Also, some people "leave" the system of flows between employment, unemployment and inactivity (due to death or permanent emigration). In turn, a new generation (i.e. people who reach the age of economic activity) flows into the system. As a consequence, the decrease in unemployment and increase in unemployment are measured on a different scale.

${ }^{2}$ Note that this reasoning is somehow simplified because in a longer term perspective, the economic situation also affects the structural unemployment level. It is also obvious that the level and nature of unemployment cannot be the only factors with decisive influence on economic policy targets.
} 
Center for Economics Policy Research (CEPR) (Unemployment 1995) and the method presented by Gärtner (1997) ${ }^{3}$.

Each of the above approaches required a different definition of natural unemployment. In NAIRU, NAWRU and NAIRCU calculation methods, focus is placed on the impact of market variables (especially including prices, wages and efficiency) on the level of unemployment. Methods based on population flows between economic activity statuses allow to take account of labour force characteristics and to calculate the structural unemployment rate at any level, limited only by data availability and sample size. This shows the usability of flow-based methods in the assessment of the rural population's situation. Conversely, NAIRU, NAWRU and NAIRCU may only help determining a reference level against which to compare the situation of the rural population (Kołodziejczak and Wysocki 2013) because they cannot be used otherwise than on an economy-wide basis (e.g. a countrywide basis).

The equilibrium unemployment level in the rural population may be estimated based on individual LFS data. One of the possible methods for equilibrium unemployment estimation for the rural population is that developed by the Centre for Economics Policy Research (CEPR) ${ }^{4}$. It consists in determining the equilibrium unemployment rate as follows (Unemployment 1995):

$$
u^{*}=\frac{s+z}{s+h+n}
$$

where:

$u^{*}$ : equilibrium unemployment rate,

$s=(E U+E N) / E$ : rate of outflow from employment (to unemployment and inactivity),

$h=\mathrm{UE} / \mathrm{U}$ : unemployment-to-employment flow rate,

$z=(N U-U N-E N) /(E+U)$ : demographic component of unemployment,

$n$ : percentage changes of labour force over the reference period,

where:

$\mathrm{E}$ : number of employed at the beginning of the reference period,

\footnotetext{
${ }^{3}$ The attention should be given to the CEPR method due to to the relative simplicity, high flexibility and the possibility of a fairly detailed disaggregation of the population under the study. More on this see: Socha and Sztanderska (2002), Kołodziejczak and Wysocki (2013).

${ }^{4}$ In Poland, one of the first studies based on that method was carried out by Socha and Sztanderska (2002) who used the Polish Labor Force Survey data from 1992-1998. They decomposed the unemployment into the cyclical and structural part and characterized its heterogeneity. Attempts to identify the nature of unemployment in Poland, based on the analysis of variables related to economic events, were also made by other authors, including Góra and Walewski (2002), Socha and Wojciechowski (2004). Other methods were used, too, including those based on NAIRU (NonAccelerating Inflation Rate of Unemployment) and NAWRU (Non-Accelerating Wage Rate of Unemployment) (see Kwiatkowski (2002a), Kwiatkowski (2002b), Kołodziejczak and Wysocki (2013). As regards rural population, a similar study was carried out by Wysocki and Kołodziejczak (2007) based on 2003-2004 data; by Kołodziejczak and Wysocki (2015) based on 2006-2009 data; and by Kołodziejczak (2018) based on 2016 data.
} 
$\mathrm{U}$ : number of unemployed at the beginning of the reference period,

EU: employment-to-unemployment flow in the reference period (number of individuals who moved from employment to unemployment),

EN: employment-to-inactivity flow,

$\mathrm{NU}$ : inactivity-to-unemployment flow,

UN: unemployment-to-inactivity flow,

UE: unemployment-to-employment flow.

Usually, the share of frictional and institutional unemployment in equilibrium unemployment is up to a few percent and is difficult to estimate. Thus, the studies on unemployment assumed that the natural (equilibrium) unemployment rate is the best approximation of the structural unemployment rate in a broader sense (Socha and Sztanderska 2002). Therefore, it is reasonable to assume that the difference between real unemployment and structural unemployment provides an approximation of the unemployment level driven by cyclical factors (i.e. cyclical or Keynesian unemployment). The estimated share of equilibrium unemployment and cyclical unemployment in real unemployment allows to formulate recommendations for state policy as regards reducing the existing real unemployment level and achieving progress towards full employment (Socha and Sztanderska 2002, Kołodziejczak and Wysocki 2013). In turn, the analysis of changes in the above rates in different population groups extracted from labour resources (or in different markets) allows to determine the reasons behind adverse events and to propose the lines of remedial action. As a major simplifying assumption, according to Kołodziejczak and Wysocki (2013), if $u^{*}>u$, real unemployment $(u)$ is likely to increase as it has not yet reached the level resulting from the impact of the labour market's structural factors (labour market mismatches); if $u^{*}<u$, real unemployment is higher than it would result from structural factors, and the difference may be roughly equated to unemployment caused by the excessively slow economic growth (which means $u$ is likely to become close to $u^{*}$ in line with the recovery of the market for goods and services).

\section{CEPR method - case study}

The estimation of equilibrium unemployment based on individual LFS data allows to describe the situation of various population groups selected by defined characteristics, such as age, gender, education, class (size) of the town of residence, voivodship, relation to agriculture etc. Actually, the only limitation is whether or not the characteristic under consideration is covered by the LFS questionnaire and whether or not enough people were surveyed in the study period to ensure the reliability of results. The time scope of the study depends, in addition to substantive matters, on the ability to access individual LFS data.

Table 1 shows an illustrative compilation of results of a CEPR study based on individual, non-weighted quarterly raw data from the 2016 Polish LFS. Changes in economic activity 
of individuals were observed in panels, i.e. pairs of quarters such that from the entire LFS sample, account is taken only of operators surveyed in both quarters of the pair under consideration (e.g. $1 Q$ and $2 Q 2016$, and then $2 Q$ and $3 Q 2016$, and $3 Q$ and $4 Q 2016$ ). Four non-published individual quarterly aggregates of raw LFS data from 2016 were used. After identifying the individuals recorded in two subsequent quarters, ca. 35,000 persons were subjected to examination (with the initial size of the quarterly LFS sample being around 100,000). To improve the quality of results (primarily to reduce the risk of incidental observations), quarterly panels were aggregated into a single yearly panel which served as a basis for further calculations. Of the many possible classification breakdowns, this paper presents the results obtained for a combination of three criteria: town class (village), relation to agriculture and gender. Non-weighted data was used in calculations; this is the only possible approach to individual LFS data because weights assigned to respondents by the Central Statistical Office are appropriate only for the sample as a whole and are not applicable to identified population groups. Therefore, the results should be regarded as approximate figures. Their informative value consists in the identification of gaps and possible trends but they cannot be considered as precise true values.

Table 1 shows data on real unemployment rate, equilibrium unemployment rate and the equilibrium-to-real unemployment ratio. If below 1 , the ratio suggests the existence of a certain level of cyclical unemployment as a component of real unemployment. If the ratio is equal to 1 , the entire real unemployment is of a structural nature. If greater than 1 , it suggests that real unemployment will increase, especially if the overall situation in the labour market deteriorates. Should this happen, the groups affected by high rates of equilibrium (structural) unemployment will be the first ones to suffer the impact of job scarcity because they are the least able to meet the needs of the labour market. Therefore, the results suggest that low levels of real unemployment among the population connected to individual farms largely result from economic prosperity. However, high unemployment rates recorded for this group suggest that unemployment may rise considerably in the event of an economic slowdown. For the landless, real unemployment is close to equilibrium employment which means it primarily depends on structural determinants. Only for landless women the equilibrium unemployment level was nearly twice the real unemployment rate. The probable factors contributing to this situation are the labour market programs for women (which improve their occupational status) as well as the impacts of women's competitive disadvantage in the labour market and the fact that women are at a greater risk of economic inactivity. A high ratio of equilibrium-to-real unemployment $\left(\mathrm{u}^{*} / \mathrm{u}\right)$ is a reason to believe that real unemployment will tend to grow in the event of an economic downturn. In the short and medium term, people involved in individual farming and landless woman, i.e. the group where the real unemployment rate is much lower than equilibrium unemployment, will be particularly severely affected. In the 
Table 1. Characteristics of the Polish rural population's occupational situation in 2016

\begin{tabular}{|c|c|c|c|c|c|}
\hline Specification & $\begin{array}{l}\text { Activity } \\
\text { rate }\end{array}$ & $\begin{array}{l}\text { Employment } \\
\text { rate }\end{array}$ & $\begin{array}{l}\text { Unemployment } \\
\text { rate }(u)\end{array}$ & \begin{tabular}{|c|} 
CEPR \\
equilibrium \\
unemployment \\
rate $\left(u^{*}\right)$ \\
\end{tabular} & $u^{*} / u$ \\
\hline Urban areas & 51.1 & 48.0 & 6.1 & 12.0 & 2.0 \\
\hline $\begin{array}{l}\text { Total for rural areas } \\
\text { including: }\end{array}$ & 51.2 & 48.0 & 6.1 & 10.1 & 1.6 \\
\hline $\begin{array}{l}\text { 1) population connected } \\
\text { with agricultural farms } \\
\text { including: } \\
\text { Gender: }\end{array}$ & 64.6 & 62.5 & 3.2 & 6.5 & 2.1 \\
\hline - men & 72.0 & 69.5 & 3.4 & 9.4 & 2.8 \\
\hline - women & 57.0 & 55.3 & 2.9 & 5.2 & 1.8 \\
\hline $\begin{array}{l}\text { Education: } \\
\text { tertiary with a degree (at } \\
\text { least } \mathrm{PhD} \text { ) and tertiary }\end{array}$ & 87.7 & 85.3 & 2.8 & -0.9 & -0.3 \\
\hline $\begin{array}{l}\text { post-secondary and } \\
\text { vocational secondary }\end{array}$ & 84.5 & 82.3 & 2.7 & 7.8 & 3.0 \\
\hline general secondary & 66.5 & 61.8 & 7.0 & 6.1 & 0.9 \\
\hline basic vocational & 80.9 & 78.5 & 3.0 & 52.6 & 17.8 \\
\hline $\begin{array}{l}\text { primary, incomplete } \\
\text { primary and without } \\
\text { education }\end{array}$ & 26.5 & 25.6 & 3.5 & 3.2 & 0.9 \\
\hline $\begin{array}{l}\text { 2) population not } \\
\text { connected with } \\
\text { agricultural farms } \\
\text { including: } \\
\text { Gender: }\end{array}$ & 44.8 & 41.3 & 7.8 & 9.4 & 1.2 \\
\hline - men & 54.1 & 49.9 & 7.8 & 6.4 & 0.8 \\
\hline $\begin{array}{l}\text { - women } \\
\text { Education: }\end{array}$ & 36.6 & 33.7 & 7.8 & 14.6 & 1.9 \\
\hline $\begin{array}{l}\text { tertiary with a degree (at } \\
\text { least } \mathrm{PhD} \text { ) and tertiary }\end{array}$ & 79.5 & 76.1 & 4.3 & 7.8 & 1.8 \\
\hline $\begin{array}{l}\text { post-secondary and } \\
\text { vocational secondary }\end{array}$ & 59.0 & 54.8 & 7.1 & 10.2 & 1.4 \\
\hline general secondary & 46.3 & 42.1 & 9.2 & 16.6 & 1.8 \\
\hline basic vocational & 52.3 & 47.9 & 8.5 & 21.1 & 2.5 \\
\hline $\begin{array}{l}\text { primary, incomplete } \\
\text { primary and without } \\
\text { education }\end{array}$ & 13.1 & 11.2 & 15.0 & 13.0 & 0.9 \\
\hline
\end{tabular}

Source: Own calculations based on unpublished individual raw data from the 2016 Polish LFS.

longer term, the adverse impact of business cycles may also deteriorate the situation of landless men if their equilibrium unemployment level "follows" the real unemployment 
rate. It is obvious that groups of population connected and not connected with agricultural farms are not internally homogeneous. The level of education is one of the features differentiating them internally. It can be noticed that the professional situation is better among higher educated people, and at the same time the threat of unemployment is smaller to them. In case of economic downturn people with basic vocational education are the most threatened by unemployment. As in the case of people with primary education and without education, their unemployment is "hiding" in individual agricultural farms (Kołodziejczak and Wysocki 2015).

Despite the equal values of the real unemployment rate in urban and rural areas (Table 1 ), the $u^{*} / u$ ratio is lower in the case of rural residents. This is quite an interesting phenomenon that can indicate a relatively strong structural foundations of low real unemployment in rural areas. However, in a broader context, this results not only from the improvement of the situation in rural areas but also from the short and medium-term economic migrations of the rural population both abroad and to cities. As in the time of political transformation, the buffer role of agriculture, which "stores" surplus labour force when the demand for labour in non-agricultural sectors is insufficient, also affects this fact. At the same time, there are two territorially diversified phenomena: hidden unemployment in agriculture and shortage of labour force in this sector, supplemented by migrations from abroad (Kołodziejczak and Wysocki 2015, Kołodziejczak 2016, Górny and Kaczmarczyk 2018).

The example discussed above shows a quite simple yet useful method for accessing knowledge on possible changes to the population's occupational situation (especially as regards unemployment). However, it may only be used as a part of a wider research project. First of all, it is necessary to draw a picture of the population based on classic labour market ratios (other than unemployment rate) and their evolution over time: labour force participation rate, employment rate, and information on vacant jobs and the broad socio-economic environment. It is also imperative to take into account a greater number of breakdowns of the population's characteristics and to use time series spanning over a minimum of several years (see Kołodziejczak and Wysocki 2015). Another requirement is to consider the levels of, and changes in, the flow rates between employment, unemployment and inactivity, and the duration of unemployment. Only when these matters are covered, the findings can be deemed reliable ${ }^{5}$. Note also that all calculations may be flawed because of the structure of the LFS questionnaire. A large part of the sample varies from one survey to another; therefore, random factors may play a certain role and the method for interpreting the results, as presented in this paper, is a simplification. To properly interpret the results, it is imperative to take into account the

\footnotetext{
${ }^{5}$ Flow rates inform of the fluidity of labor force. In turn, the average duration of unemployment is an indirect indicator of the structural or other nature of unemployment: the longer the duration, the more likely is a significant contribution of structural factors (see Socha and Sztanderska 2002, Kołodziejczak and Wysocki 2013).
} 
specificity of geographic areas covered by the study; the economic situation and its determinants; the legal and institutional environment; the socio-cultural characteristics; and many other aspects, as adequate for the study (cf. Kołodziejczak 2016).

\section{Conclusion}

The method for and example of estimating the equilibrium unemployment presented in this paper are based on micro-data, i.e. on observed changes in labour market statuses of individuals covered by the Polish LFS. As a consequence, this method may be used for various population groups selected by different criteria (age, gender, education, place of residence, relation to agriculture, track record etc.). The above criteria may be used in any combination (for instance, to analyse the situation of women with vocational education related to agriculture). Calculating the equilibrium unemployment level for particular rural population groups selected by defined characteristics, assessing how they evolve over time, and comparing the results between different population groups (e.g. urban dwellers) can be a basis for drawing conclusions on the determinants of changes in economic activity and on the structural or cyclical nature of unemployment. This information is essential for a proper selection of measures taken to counteract adverse developments in the labour market, and enables a more efficient search for solutions designed to improve the rural population's occupational and economic status.

However, the estimated level of equilibrium unemployment itself is not enough to draw the right conclusions; it must be a part of wider research projects. First of all, it is necessary to draw a picture of the population based on classic labour market ratios (other than unemployment rate) and their evolution over time: labour force participation rate, employment rate, and information on vacant jobs and the broad socio-economic environment. Also, time series spanning over a minimum of several years must be used. Another requirement is to consider the levels of, and changes in, the flow rates between employment, unemployment and inactivity, and the duration of unemployment in particular population groups.

The research results obtained from the flow-based analysis should be interpreted in the broad context of the economic, social and institutional environment. Only such an analysis let us avoid dangerous simplifications and draw the correct conclusions.

Both the traditional approach to market research and other, "dynamic" methods based on the analysis of flows to/from employment, unemployment and inactivity provide much valuable information. Therefore, the use of "dynamic" methods should not be a reason for a total shift away from traditional research; both approaches are not competitive but complementary to each other. 


\section{Acknowledgments}

The paper is funded by National Science Centre within the MINIATURA research project No. NCN DEC-2017/01/X/HS4/00565, titled "Determinants of Economic Activity of the Rural Population in Poland. Opportunities to reduce hidden unemployment in agriculture" ("Determinanty aktywnosci ekonomicznej ludnosci wiejskiej w Polsce. Mozliwości redukcji bezrobocia ukrytego w rolnictwie").

\section{Reference}

BURDA M., WYPLOSZ CH. (1995). Makroekonomia. Podręcznik europejski. Państwowe Wydawnictwo Ekonomiczne, Warszawa.

DARBY, M., HALTIWANGER, J., PLANT, M. (1986). Unemployment Rate Dynamics and Persistent Unemployment under Rational Expectations. American Economic Review 75(4).

GÄRTNER, M. (1997). A Primer in European Macroeconomics, Prentice Hall, London.

GÓRA M., WALEWSKI M. (2002). Bezrobocie równowagi w Polsce - wstępna analiza i próba oszacowania. Polska Gospodarka. Tendencje - oceny - prognozy. Nr 4 (15).

GÓRNY, A., KACZMARCZYK, P. (2018). A known but uncertain path: The role of foreign labor in Polish agriculture. Journal of Rural Studies, doi.org/10.1016/j.jrurstud.2017.12.015.

HALTIWANGER J. (1991). The natural Rate of Unemployment, in: The New Palgrave. A Dictionary of Economics, $\mathrm{t}$ 3. The Macmillan Press LTD, London.

Individual, non-weighted quarterly raw data from the 2016 Polish LFS (BAEL).

JACKMAN R, ROPER R. (1987). Structural Unemployment, Oxford Bulletin of Economics Performance Discussion Papers, nr 349, London 1997

KOŁODZIEJCZAK W. (2016). Nadwyzka zatrudnienia w polskim rolnictwie - projekcja na tle panstw Unii Europejskiej Zeszyty Naukowe SGGW w Warszawie Problemy Rolnictwa Swiatowego, t. 16(31), vol. 1.

KOŁODZIEJCZAK, W. (2018). Labour force in Polish rural areas after Poland's accession to the European Union. Proceedings of the 2018 International Conference "Economic Science For Rural Development", No 47 Jelgava, LLU ESAF, 911 May 2018, DOI 10.22616/ESRD.2018.000

KOŁODZIEJCZAK, W., WYSOCKI, F. (2013). Identyfikacja charakteru bezrobocia w Polsce w latach 20062009. Gospodarka Narodowa, 9(265), 29-52.

KOŁODZIEJCZAK, W., WYSOCKI, F. (2015). Determinanty aktywności ekonomicznej ludności wiejskiej w Polsce (Determinants of economic activity of the rural population in Poland). Wyd. UP w Poznaniu, Poznań.

KWIATKOWSKI E. (2002a). Strukturalne determinanty naturalnej stopy bezrobocia. Bank i Kredyt, No. 1112.

KWIATKOWSKI E. (2002b). Bezrobocie. Podstawy teoretyczne. Wyd. Nauk. PWN, Warszawa.

SOCHA M., SZTANDERSKA U., (2002). Strukturalne podstawy bezrobocia w Polsce. Wyd. Nauk. PWN, Warszawa.

SOCHA, M., WOJCIECHOWSKI, W. (2004). Koncepcja NAIRU, dezinflacja a druga fala bezrobocia w 
Polsce, Bank i Kredyt, 35(3).

SZTANDERSKA U. (1999). Metoda przepływów - zastosowanie w prognozowaniu popytu na pracę w przekroju zawodowym. Studia i materiały, Tom II. RCSS, Warszawa.

TYROWICZ J. (2011). Histereza bezrobocia w Polsce. Wyd. Uniwersytetu Warszawskiego, Warszawa.

Unemployment: Choices for Europe (1995). CEPR London. 